\title{
Para entender o Serviço Social na área sociojurílica*
}

\section{To understand Social Work in the socio-legal sphere}

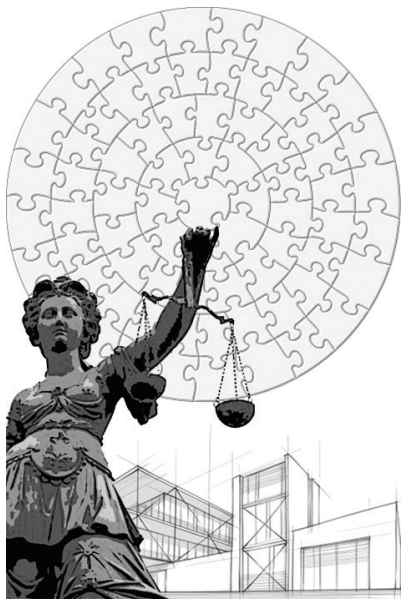

\section{Elisabete Borgianni**}

Resumo: Tendo como base as contribuições de Lukács para pensar o Direito, o artigo aborda as principais determinações do Serviço Social na área sociojurídica e discute se a melhor denominação seria "campo" ou "área" sociojurídica. Aponta ainda alguns dos desafios e possibilidades de atuação que estão postos aos assistentes sociais que trabalham nos espaços sócio-ocupacionais próprios do universo jurídico ou que com ele têm interfaces.

Palavras-chaves: Serviço Social na área sociojurídica. Direito. Justiciabilidade dos direitos sociais. Instituições do sociojurídico.

\begin{abstract}
Based on Lukács's contributions for the analysis of Law, in the article we discuss both the main characteristics of Social Work in the socio-legal sphere, and the nuances between a socio-legal "area" and a socio-legal "field". Furthermore, we identify some of the challenges faced by social workers engaged in socio-occupational activities that are characteristic of or correlated with the judicial system.
\end{abstract}

Keywords: Social work in the socio-legal sphere. Law. Justiciability of social rights. Socio-legal institutions.

* Recupero, neste texto, parte significativa (inclusive com reprodução literal de algumas passagens) das reflexões que fiz no processo de assessoria ao Grupo de Trabalho do Campo Sociojurídico do Conjunto CFESS/ Cress, as quais estão registradas no texto não publicado intitulado "O Serviço Social no 'campo sociojurídico': primeiras aproximações analíticas a partir de uma perspectiva crítico-ontológica” (cf. Borgianni, 2013).

** Assistente social do Tribunal de Justiça do Estado de São Paulo, mestre e doutora em Serviço Social pela PUC-SP, São Paulo, Brasil, presidente da Associação dos Assistentes Sociais e Psicólogos do Tribunal de Justiça do Estado de São Paulo (AASPTJ/SP), gestões 2009-13 e 2013-17. E-mail: beteju@terra.com.br. 


\section{Introdução}

presente artigo pretende somar-se ao esforço coletivo que vem sendo feito
para conhecer, apoiar e desenvolver, na direção do projeto ético-político
do Serviço Social brasileiro, o trabalho realizado pelos assistentes sociais
nos diversos espaços sócio-ocupacionais pertencentes ao até aqui chamado "campo sociojurídico". Digo "até aqui" porque após estudos recentes venho desenvolvendo a compreensão de que a esfera do "jurídico", antes de configurar-se como um campo específico configura-se, para nós, assistentes sociais, como uma área de atuação e também de produção de conhecimento (a área sociojurídica).

Minha pretensão neste artigo que, como poderá ser observado, está baseado em estudos bastante preliminares, é apenas apontar alguns elementos fundamentais para se pensar o significado da atuação do assistente social nessa área, não adentrando, por hora, nas especificidades de suas institucionalidades - como Tribunais de Justiça, Sistema Prisional, Ministério Público, Defensorias etc.

Entendendo que a busca da particularidade dos espaços que conformam o sociojurídico não pode prescindir de uma caracterização "geral", proponho que trabalhemos a partir da perspectiva crítico-ontológica para a elucidação dos elementos centrais e comuns que comparecem à intervenção dos assistentes sociais que aí atuam. Esse esforço haverá de ser completado com o trabalho urgente e necessário de ir à busca das particularidades de cada uma das institucionalidades que conformam a área — trabalho que já começa a ser realizado por alguns assistentes sociais que estão atuando nas instituições do sociojurídico, o que certamente contribuirá com o aperfeiçoamento do Serviço Social brasileiro.

Assim, o que estou buscando aqui é apenas e tão somente captar as mediações históricas fundamentais que podem explicitar o significado social da profissão (tal como originariamente formulado com precisão por Marilda Iamamoto), no rico e problemático universo sociojurídico.

\section{0 uso da expressão "sociojurídico" no Serviço Social brasileiro: como tudo começou}

O termo "sociojurídico" foi vinculado pela primeira vez ao Serviço Social brasileiro no momento de composição do número 67 da revista Serviço Social \& 
Sociedade, editada em setembro de 2001, quando inaugurava-se a série de Números Especiais desse periódico. A elaboração do referido número ocorreu após solicitação do editor, José Xavier Cortez, de que a assessoria editorial da área (pela qual eu já respondia na ocasião), fizesse um projeto para a edição de números especiais da revista voltados especificamente para temas com os quais os assistentes sociais estão confrontados diretamente em seu cotidiano profissional. Na época (como até hoje), Cortez vinha recebendo várias solicitações de que os livros, bem como o periódico editado por sua editora, contemplassem temas e demandas com os quais os assistentes sociais viam-se envolvidos em sua prática diária. E muitas das solicitações partiam de assistentes sociais que atuavam na área sociojurídica.

Foi quando sugeri ao Conselho Editorial que analisasse a possibilidade de iniciar a referida série com artigos relacionados à área penitenciária e judiciária, atingindo, com essa publicação, tanto os assistentes sociais que fazem os laudos periciais para juízes das Varas da Infância e Juventude (e que trabalham com casos de adoção, violência contra crianças, ato infracional de adolescentes etc.) e também das Varas de Família e Sucessões (casos de disputa de guarda de filhos, interdições de idosos ou doentes mentais, entre outros), quanto aqueles que trabalham dentro do sistema prisional. No momento da escolha para o melhor termo a compor o chamado "olho de capa" do referido número, o Conselho Editorial fez várias sugestões, e a opção foi pela expressão "Temas Sociojurídicos". Foi assim, portanto, a primeira vez que ocorreu a vinculação do termo "sociojurídico" ao Serviço Social brasileiro. $^{1}$

Em seguida, ocorreria o $10^{\circ}$ Congresso Brasileiro de Assistentes Sociais, no Rio de Janeiro, e seus organizadores pensaram em criar naquele CBAS, pela primeira vez na história de nossos congressos, uma seção temática, ou um painel específico, para aglutinar os profissionais que trabalham no sistema penitenciário e no Judiciário, e consultaram-me sobre a expressão adequada para nomear a referida seção, ao que sugeri que poderiam também utilizar o termo sociojurídico, para chamar a atenção de todos os colegas que trabalham nos espaços sócio-ocupacionais que têm interface com o universo jurídico. Ali, no $10^{\circ} \mathrm{CBAS}$, além de ter sido lançado o $\mathrm{n}$. 67 da revista Serviço Social \& Sociedade, elaborou-se pela primeira vez uma agenda de compromissos que incluiriam ações relacionadas a essa área. A partir de 2002,

1. O Comitê Editorial do n. 67 era formado pelas professoras Andrea Almeida Torres, Eunice Teresinha Fávero, Gizelda Morato Franzino, Sílvia Helena Pinho Chuairi, com colaboração especial de Maria Rachel Tolosa Jorge. Todas com inserção e/ou experiência profissional na área. 
vários Conselhos Regionais de Serviço Social do Brasil começaram também a criar suas Comissões Sociojurídicas que seriam, então, compostas por membros de direção e assistentes sociais que atuam no Tribunal de Justiça, no Ministério Público, nas instituições de cumprimento de medidas socioeducativas e no sistema prisional. O primeiro a fazê-lo foi o Cress $/ 7^{a}$ Região-RJ, então presidido por Hilda Correa de Oliveira, e tendo significativo protagonismo de colegas daquela gestão que trabalhavam (e ainda trabalham) na área, como Andreia C. A. Pequeno (Tribunal de Justiça), Tânia Dahmer Pereira e Newvone Ferreira da Silva (Sistema Prisional). Andreia Pequeno relata também que em novembro de 2003 foi realizada uma Oficina Temática no $2^{\circ}$ Congresso Paranaense de Assistentes Sociais e, naquele mesmo ano, "houve a incorporação, na grade curricular do curso de graduação da Faculdade de Serviço Social da Universidade do Estado do Rio de Janeiro, de uma disciplina sobre o campo sociojurídico" (Pequeno, 2004, p. 11). Depois disso, já estando na direção do Conselho Federal de Serviço Social, compondo a gestão de 2002-2005, sob a lúcida presidência de Lea Braga, pude contribuir, juntamente com um grupo de colegas do CFESS e do Cress/Paraná, com a organização do I Seminário Nacional do Serviço Social no Campo Sociojurídico, que ocorreu em 2004, em Curitiba. A realização desse seminário havia sido uma deliberação do Encontro Nacional CFESS/Cress realizado em Salvador, em 2003, a partir de uma proposta encaminhada ao CFESS pelo Cress $/ 7^{\text {a }}$ Região (Pequeno, idem).

Anoto que foi talvez naquele momento de organização do I Seminário que se utilizou pela primeira vez a expressão "Serviço Social no campo sociojurídico". Foge-me totalmente à memória se a direção do CFESS chegou a debater ou não, na ocasião, se a melhor expressão seria "campo" ou "área". A proposta enviada pelo Cress $/ 7^{a}$ Região foi incorporada para ser levada ao Encontro Nacional, tendo sido ali votada sem grandes questionamentos sobre a terminologia.

O que recordo com muita clareza é que, tanto nós do CFESS, quanto os colegas do Cress/RJ tínhamos a preocupação de não incentivar nenhuma ideia de que haveria um Serviço Social próprio dessa área, algo, por exemplo, como um "Serviço Social Sociojurídico". Ao contrário, tínhamos a firme convicção de que seria necessário sempre explicitar o entendimento de que a profissão é uma só e atua em diferentes espaços sócio-ocupacionais, entre eles os que têm interface com o jurídico.

O I Seminário Nacional realizado em Curitiba, em 2004, foi então de grande importância, não só por seu pioneirismo, mas pela qualidade da contribuição trazida pelas reflexões de assistentes sociais da área e de palestrantes bastante próximos 
da temática. Porém o mais importante foi o conteúdo da agenda política ali deliberada que, conforme relato de Eunice Fávero, recomendava, entre outros pontos:

que o Conjunto CFESS/Cress incorpore a denominação "campo das práticas sociojurídicas"; e fomente a articulação de comissões do campo sociojurídico em todas as regiões" com o objetivo de "discutir e sistematizar as atribuições, competências e aspectos éticos a partir do interior do projeto ético-político, o que certamente incentivaria a produção de conhecimentos a respeito das práticas desenvolvidas nas diversas áreas. (Fávero, 2012, p. 123)

Fávero lembra ainda que:

O CBAS de 2001, mais os de 2004 e 2007, também definiram políticas para esse campo, sendo que a Agenda do $12^{\circ}$, realizada em Foz do Iguaçu em 2007, explicitava como compromissos:

"Discutir politicamente os temas das violências, visando superar a fragmentação das práticas, a naturalização da barbárie, a eliminação e criminalização dos pobres; pensar a indissociabilidade da discussão das violências do projeto ético-político do Serviço Social"; "promover a reflexão sobre a ampliação dos espaços de trabalho no campo sociojurídico; refletir sobre o investimento no Estado Penal em detrimento do Estado Social, e priorizar práticas de prevenção; explicitar a denominação Serviço Social no Campo Sociojurídico e não Serviço Social Sociojurídico; compreender o estudo social e a perícia social com objetivos de efetivação de direitos - avançar em sua construção interdisciplinar e na relação teoria x prática"; "lutar e agilizar gestões para consolidação da rede nacional de proteção especial (Creas). (Agenda, $12^{\circ} \mathrm{CBAS}$, apud Fávero, 2012, p. 124; grifos meus)

Foram os profissionais da área sociojurídica que estavam presentes no CBAS de Foz do Iguaçu que solicitaram ao CFESS a organização de outro evento específico, o que redundou no II Seminário do Serviço Social Sociojurídico, realizado em 2009 em Cuiabá. $^{2}$

2. Vale a pena recuperar o registro de Fávero (2012, p. 125): “[...] no $12^{\circ} \mathrm{CBAS}$, de Foz do Iguaçu, aproximadamente quarenta profissionais, de vários estados brasileiros, que estão na intervenção cotidiana ou desenvolvendo estudos e pesquisas acadêmicas sobre esse campo, articularam-se para discutir e solicitar do CFESS a realização do II Encontro Sociojurídico. Na ocasião, a justificativa era a necessidade da continuidade de articulação e premência dos debates em torno das questões teóricas, operacionais e ético-políticas que se impõem na realidade social contemporânea. Conforme a solicitação encaminhada ao CFESS, dez dos(as) 
Além desses fatos, penso ser pertinente também resgatar aqui a importância de vários eventos realizados por colegas em diferentes pontos do Brasil, preocupados com a temática da atuação do assistente social nessa área. Entre eles destaco um que ocorreu em Natal (RN), no ano de 2002, denominado Serviço Social e Assistência Sociojurídica na Área da Criança e do Adolescente: Demandas e Fazer Profissional, promovido pela base de pesquisa Trabalho Profissional e Proteção Social, sob a coordenação da professora doutora Maria Célia Nicolau.

Destaco a importância daquele evento de Natal, entre tantas outras iniciativas, pelo fato de os organizadores terem convidado a professora Marilda Iamamoto para ali fazer uma conferência, que meses depois seria transformada pela autora em valioso texto, publicado sob o título "Questão social, família e juventude: desafios do assistente social na área sociojurídica”, como posfácio do livro Política Social, família e juventude: uma questão de direitos, organizado por Mione Sales, Maurílio C. de Matos e Maria Cristina Leal, publicado em 2004 pela Cortez Editora e lançado por ocasião do I Seminário Nacional, de Curitiba. Ao que eu saiba esse foi o primeiro texto de uma das principais pesquisadoras brasileiras do Serviço Social dedicado a essa temática, embora Marilda nunca tenha atuado na área. Note-se que nesse texto a autora usará sempre a terminologia "área ou esfera sociojurídica", e não "campo", porém sem entrar no mérito dessa questão terminológica (cf. Iamamoto, 2004, p. 261-314). ${ }^{3}$

Essa, digamos, "percepção" dos assistentes sociais brasileiros de que era necessário olhar com mais cuidado e profundidade para os desafios que estão postos aos que atuam na área sociojurídica - à qual a revista Serviço Social \& Sociedade, bem como o conjunto CFESS/Cress conseguiram captar e dar voz -, é tributária do próprio movimento da história recente em nosso país, que engendrou tanto uma crescente judicialização dos conflitos sociais, quanto a justiciabilidade dos direitos sociais. Veremos isso com mais detalhes adiante, mas antes cabe refletir sobre o que compõe essa área que tem interface com o direito e com o universo jurídico.

profissionais daquele grupo foram escolhidos para compor uma Comissão Provisória, para as primeiras tratativas sobre um possível segundo encontro. Havia colegas do Espírito Santo, Pará, Paraná, Minas Gerais, Rio de Janeiro, Bahia, Maranhão, São Paulo, Distrito Federal, entre outros".

3. Em 2005, Marilda Iamamoto daria também sua contribuição à área aceitando prefaciar a obra O Serviço Social e a psicologia no judiciário: construindo saberes, conquistando direitos, organizada por Eunice T. Fávero, Magda J. R. Melão e Maria Rachel Tolosa Jorge, e editada pela Cortez, em parceria com a Associação dos Assistentes Sociais e Psicólogos do Tribunal de Justiça do Estado de São Paulo (AASPTJ/ SP) (ver Iamamoto, 2005). 


\section{Serviço Social no "campo" ou na "área" sociojurídica? A partir de que bases delimitar o que compõe essa área?}

Quem primeiro trouxe-nos uma tentativa de definição mais "arredondada" foi Eunice Teresinha Fávero, quando colocou que "o campo (ou sistema) sociojurídico diz respeito ao conjunto de áreas em que a ação social do Serviço Social articula-se a ações de natureza jurídica, como o sistema penitenciário, o sistema de segurança, os sistemas de proteção e acolhimento, como abrigos, internatos, conselhos de direitos, dentre outros" (Fávero, 2003, p. 10). Em outra ocasião, a mesma autora fez elucidativa interpretação do papel social cumprido pelas instituições ou organizações próprias do sociojurídico: “[...] organizações que desenvolvem ações, por meio das quais aplicam sobretudo as medidas decorrentes de aparatos legais, civil e penal, e onde se executam determinações deles derivadas" (Fávero, 2012, p. 122-123). E a mesma completou: “[...] nessas áreas, direta ou indiretamente, trabalhamos com base normativa legal e em suas interpretações pelos operadores jurídicos" (Idem).

No II Seminário Nacional, procurei também dar uma contribuição no sentido de definir melhor esse "campo" ou área e propus que o Serviço Social brasileiro o perspectivasse de forma mais ampliada e profunda, avançando em relação ao que todos vínhamos fazendo, que era pensá-lo basicamente a partir das organizações ou instituições que o compõem. Sugeri, na ocasião, que buscássemos compreender melhor o que é esse "jurídico" de que tanto estávamos falando e recuperei uma das ideias correntes no mundo jurídico que me parece muito elucidativa, segundo a qual o jurídico é, antes de tudo, o lócus de resolução dos conflitos pela impositividade do Estado. E ressaltei, naquele momento, que essa característica, por si só, já coloca grandes desafios éticos e políticos para a intervenção do assistente social (Borgianni, 2012, p. 167). Na oportunidade chamei a atenção para algo que marca muito o trabalho de qualquer assistente social - ou de outro trabalhador que tenha que desempenhar suas funções de "perito" nesse "campo" - , que são as determinações complexas que emanam das polaridades antitéticas próprias da esfera jurídica, por exemplo, aquelas que considero uma das mais marcantes: garantir direitos em um espaço ou sistema que é também aquele onde se vai responsabilizar civil ou criminalmente alguém (Idem, p. 167-168).

Também naquele II Seminário, o promotor de Justiça Wanderlino Nogueira Neto fez observações que nos ajudam a pensar nosso trabalho nessa área. São pontuações com significativo conteúdo heurístico, principalmente porque feitas por 
alguém do universo jurídico. $\mathrm{O}$ dr. Wanderlino iniciou sua conferência colocando que o tema para o qual havia sido convidado a falar interessaria tanto a seu coletivo "na esfera da proteção jurídico-social dos direitos humanos, quanto aos/às assistentes sociais com atuação na esfera da proteção sociojurídica dos direitos socioassistenciais". E em seguida pontuou:

Aqui estou eu, um operador da Defesa dos Direitos Humanos, a falar para operadores/ as do Serviço Social: ambos/as a atuarem, cada qual a seu modo, na garantia do acesso ao Valor-Justiça, tanto em sistemas de políticas públicas, quanto no sistema de justiça. Isto é, a fazer do acesso a esses dois sistemas públicos, um “direito do cidadão e um dever do Estado". Essas definições dos nossos campos de ação — assemelhados mas não iguais - já balizam inicialmente nosso enfoque para tratar do sucesso, do insucesso e das limitações ou possibilidades de enfrentamento da questão social, em seu aspecto estrutural, via judicializações conjunturais e pontuais de conflitos de interesses e de demandas, nas relações sociais. (Nogueira Neto, 2012, p. 23)

Temos então, até aqui, o registro das pouquíssimas tentativas de definição ou de delimitação do que caracteriza a atuação do assistente social nesse campo ou área que tem interface com o jurídico.

Avancemos, portanto, na reflexão utilizando-nos das mesmas bases teórico-metodológicas e históricas que dão sustentação ao projeto ético-político do Serviço Social brasileiro, ou seja, a perspectiva crítico-ontológica com que Marx analisou o mundo burguês e que restou tão bem explorada por Georg Lukács em suas reflexões a partir dos anos 1930 (essa perspectiva foi abordada em Borgianni, 1997).

\section{1 "Campo jurídico" - um conceito pouco elucidativo}

De forma sintética, podemos dizer que campo jurídico é um conceito que foi formulado por Pierre Bourdieu, que o define como determinado espaço social no qual os chamados "operadores do direito" - magistrados, promotores e advogados - "concorrem pelo monopólio do direito de dizer o Direito" (Bourdieu, apud Shiraishi Neto, 2008, p. 83; Gaglietti, 1999, p. 84-85).

Essa é uma definição que, em sua imediaticidade, parece refletir de fato algo que pode ser observado quando se trabalha nessa área: há um indiscutível e permanente debate do cotidiano do universo jurídico, entre juízes, promotores e advoga- 
dos, que buscam os elementos que melhor permitam, a cada um, dizer o Direito, diante das questões ou dos conflitos jurídicos com os quais se confrontam.

Isso até incita-nos a levantar algumas perguntas: - Até que ponto esse é um campo específico e/ou privado dos chamados “operadores do Direito?", Qual seria a peculiar contribuição do Serviço Social nesse campo jurídico, espaço onde se disputa $o$ direito de dizer o Direito?, O que teriam a aportar a esse espaço os assistentes sociais que se querem coerentes com o projeto ético-político da profissão? São perguntas que tentarei responder mais adiante.

Contudo, para avançar um pouco mais, é preciso recuperar o significado também do Direito e de universo jurídico que, à primeira vista, parecem construções sociais que foram sendo erguidas no processo do desenvolvimento do ser humano através da história. Construções que aparentemente teriam tido o escopo de afastar os homens progressivamente de suas "barreiras naturais", fazendo com que superassem seus "sentimentos inatos de vingança" e também as formas instintivas - e por vezes bárbaras - de resolução de conflitos.

Sob essa perspectiva, que eu diria "ingênua", o direito e o universo jurídico teriam sido construídos como um conjunto de regras que objetivam deveres e prerrogativas, bem como delimitam quem deve garanti-los (especialistas, magistrados, promotores, advogados). Todo esse processo ocorreria ao longo de uma caminhada linear e rumo à construção de um sistema de ordenações normativas em que um ente superior aos interesses individuais e privados - o Estado - também teria sido erguido com a responsabilidade de equilibrar ou "pacificar" relações conflituosas entre os indivíduos.

É bastante comum ver análises "históricas" sobre a evolução do direito ou do "estado de direito" que refletem esse tipo de visão simplista e mecanicista, segundo a qual a civilização teria marchado decididamente no curso da história no sentido de implantar regras e normas que, ao fim e ao cabo, formariam o chamado "império das leis", a partir do qual as relações singulares e coletivas poderiam ser reguladas. O Estado apareceria aí, então, como o elemento garantidor da chamada "paz social" frente aos "naturais" conflitos de interesses de uma sociedade formada por indivíduos que seriam iguais em termos das oportunidades que a sociedade pode oferecer-lhe e diferentes em suas capacidades de usufruí-las. A partir dessa visão idílica e falseadora do real, legalidade e legitimidade formariam os pressupostos formais do chamado estado de direito, segundo o qual "o homem" seria o centro e a razão do "sistema social". 
Essas são definições ou explicações que, algumas delas reais (no caso da de Bourdieu, que citei anteriormente), ou mistificadoras neste segundo caso, parecem levar-nos apenas ao vestíbulo do conhecimento, não fornecendo a clareza sobre as concretas determinações dessas esferas de objetivação do ser social que são o universo jurídico e o direito.

\subsection{A perspectiva lukacsiana para pensar o Direito e o universo jurídico}

A aproximação mais fecunda com as questões próprias dessa esfera pode ser alcançada se a análise partir dos fundamentos crítico-analíticos ou teórico-metodológicos que emanam da perspectiva crítico-dialética e ontológica de Marx, apontada com tanta profundidade por Georg Lukács.

Em obra sintética e esclarecedora, Vitor Bartoletti Sartori (2010) se propôs a pensar o Direito a partir dessa perspectiva. Em virtude de sua clareza e fidelidade à fonte lukacsiana é que utilizarei muitas passagens literais dessa obra, citando somente as páginas de onde foram extraídas. Recorrerei também às análises feitas por outros autores, como E. Pasukanis (1977), e R. Carli (2012), para demarcar elementos centrais sobre o direito e a política como duas das importantes e centrais objetivações do ser social.

Por tratar o Direito como parte de uma totalidade histórica, calçando suas análises nas categorias fundamentais do método de Marx, é que Lukács consegue avançar em relação a inúmeros autores que se debruçaram sobre esse tema nos últimos dois séculos e que, por vezes, ficam aprisionados nos limites do idealismo ou do positivismo.

Nessa direção, é pertinente resgatar, logo de início, que Lukács, ao tratar das objetivações do homem no processo de sua constituição enquanto ser social, ressalta que o mesmo desenvolve duas formas de pôr teleológico: aquela voltada diretamente para a transformação da natureza e aquela voltada para, digamos, o influenciar de outros homens. É o que ele denomina de teleologias primárias e secundárias - ambas intimamente ligadas entre si. Assim, falando de modo resumido, enquanto o trabalho em sentido estrito é uma posição teleológica primária - e eternamente necessária - , pela qual os homens se apropriam dos elementos da natureza para produzir os meios de sua subsistência, as posições secundárias são 
aquelas que visam "extrair um determinado comportamento coletivo" (cf. Carli, 2012, p. 9). ${ }^{4}$

\section{No exemplo translúcido de Carli:}

o trabalho significa a transformação de pedras e madeiras em instrumentos [...], já outras esferas do ser social, como a política, por exemplo, não transformam a natureza; procuram agir sobre a sociedade. As posições secundárias não agem sobre a natureza, mas sim sobre um grupo de homens. A ação política é uma posição teleológica secundária precisamente porque procura extrair um determinado comportamento de um coletivo. Um partido político procura, em suas ações, produzir uma reação específica de indivíduos determinados, seja para a conservação da ordem estabelecida ou para sua transformação (Idem).

E Carli recolhe de Lukács uma observação sobre a política que cabe também para o direito:

Com o desenvolvimento histórico posterior, isto é, com o surgimento das sociedades classistas, as posições teleológicas secundárias tornam-se formas de ideologia, que são as modalidades de comportamento através das quais os homens se fazem conscientes dos conflitos postos e "neles se inserem mediante a luta" (p. 18).

Resumindo, tanto o direito como a política são vistos por Lukács como expressões das teleologias secundárias. Aquelas que, diferentemente dos atos teleológicos voltados para a transformação da natureza para obtenção dos meios de vida - e que estão englobadas nas crescentemente complexas e mediadas relações econômicas —, expressam as mediações que se criam e se institucionalizam a partir de atos teleológicos secundários, dando as formas da totalidade social no universo burguês.

Ressaltando que "secundário" nesse contexto não quer dizer menor ou de menor importância, mas apenas o lugar que ocupa em meio à totalidade social, Sartori aponta que o Direito é um complexo que não possui caráter fundante, mas que não pode ser dissociado daquela esfera do ser social na qual ele produz seus meios de vida - a esfera econômica (cf. Sartori, 2010, p. 94).

4. Ou nas próprias palavras do filósofo húngaro: “[...] as posições teleológicas necessárias são [...] de duas formas: aquelas que visam transformar, com finalidades humanas, objetos naturais [...] e aquelas que tencionam incidir sobre a consciência dos outros homens para impedi-los de executar as posições desejadas" (Lukács, apud Sartori, 2010, p. 54). 
Assim é que Lukács, ao se indagar sobre o "lugar" do Direito na práxis social, observa que ele tem importante papel nas esferas relacionadas à reprodução social, configurando-se como uma mediação que é própria da sociedade burguesa - e que somente aí se desenvolve enquanto tal com toda a sua completude. Ou seja, embora em tempos pretéritos tenham existido variadas formas de regulação dos conflitos humanos, bem como de "reparação de danos", e de responsabilização daqueles que os causaram a alguém ou a alguma coisa, ${ }^{5}$ aquilo que realmente pode ser denominado com a expressão direito só surge em determinado estágio da trajetória do ser social ao longo da historia e quando estão presentes outras determinações peculiares àquele estágio.

O que o filósofo magiar demarcará então, com muita precisão, assim como já o fizera Marx, é que somente quando presentes categorias históricas como classe social e Estado é que surge a ideia de direito como "conjunto de normas jurídicas de acordo com as quais a sociedade se organiza com a finalidade de manter a ordem e o convívio social" (Sartori, 2010, p. 9).

Assim, a aparência do direito como algo acima dos interesses antagônicos das classes sociais, como um "sistema autossuficiente calcado na cientificidade dos especialistas e na precisão do reflexo jurídico, supostamente capaz de captar as necessidades sociais como um todo" (Sartori, 2010, p. 107), só se resolve em determinada quadra histórica: justamente aquela que faz nascer também as reificadas relações burguesas de produção, regidas pelo capital. Aliás, F. Engels já havia mostrado como o surgimento de especialistas dessa área e a autonomia relativa que o complexo jurídico vai adquirindo são produtos do desenvolvimento social. Segundo o próprio Bourdieu, em "uma carta dirigida a Conrad Schmidt, Engels observa o aparecimento do direito enquanto tal, ou seja, como 'esfera autônoma', acompanhando os progressos da divisão do trabalho que levam à constituição de um corpo de juristas profissionais" (Bourdieu, 1999, p. 101).

5. Ranieri Carli mostra que Lawrence Krader estudou alguns povos comunitários e sua organização do poder (e também da "justiça", diria eu). [Krader] "verificou que entre os esquimós, por exemplo, era constituído o seguinte arranjo de forças: "não possuem chefes, nem conselhos consultivos, nem assembleias deliberativas, embora pratiquem uma forma de liderança econômica individual: na caça da baleia, o dono do barco tem domínio sobre a tripulação, e o direito primordial sobre a presa'. As querelas eram resolvidas de modo peculiar: por meio do 'duelo cantado'. O queixoso e o acusado cantam canções alternadas em que relatam as suas versões sobre o incidente. 'O ofendido relata os danos a ele e busca reparação; o que se defende afirma a inocência, defendendo-se de outro modo. A decisão entre acusado e acusador é tomada pela comunidade" (Krader, apud Carli, op. cit., p. 12). 
A relação da gênese do direito com o desenvolvimento das formas econômicas mercantis, bem como, naturalmente, com as formas politicas que se erguem a partir dessa base material - o Estado burguês que dá sustentação às profundas desigualdades de classes que daí surgem, por exemplo - é é vista com clareza por Lukács, assim como já estava presente na tese seminal de E. Pasukanis sobre o significado do direito numa sociedade cujas relações fundamentais são baseadas em processos nos quais os produtores do trabalho humano ficam igualados na forma de mercadoria. De fato, como demonstrado genialmente por Marx, a forma mercadoria "esconde" o real valor que tem o trabalho humano - enquanto produtor de possibilidades novas diante da natureza e dos outros homens -, sob o manto alienante e fetichizante do valor de troca e das equivalências mistificadas que esse processo metabólico produz.

Outrossim, deve-se observar mais uma vez que a análise lukasciana, na esteira de como procedera Marx na relação com seus objetos de estudo, não separa artificiosamente os elementos de uma totalidade concreta. Eles perspectivam o desenvolvimento do ser social burguês sempre como um processo unitário. Por isso, para Lukács era impossível pensar o direito e suas categorias centrais sem resgatar aquelas que fazem parte do desenvolvimento unitário - e contraditório — da sociedade do capital, como propriedade privada, divisão social do trabalho, classes sociais, Estado etc. Desse modo, tão ou mais importante do que apenas localizar a gênese histórica do direito no surgimento da sociedade de classes é conseguir captar as forças contraditórias - ou as "negatividades" que lhe conferem o movimento - que operam em seu interior, bem como os processos que as encobrem.

Nesse sentido, foi Pasukanis quem conseguiu, a partir das contribuições de Marx, descrever um dos (senão o principal) vínculos problemáticos que se estabelecem entre a forma jurídica e a mercantil:

Marx nos mostra a condição fundamental, enraizada na estrutura econômica da própria sociedade, da existência da forma jurídica, isto é, da unificação dos diferentes rendimentos do trabalho segundo o princípio da troca de equivalentes. Ele descobre, assim, o profundo vínculo interno existente entre a forma jurídica e a forma mercantil. Uma sociedade que é constrangida, pelo estado de suas forças produtivas, a manter uma relação de equivalência entre o dispêndio de trabalho e a remuneração, sob uma forma que lembra, mesmo de longe, a troca de valores-mercadorias, será constrangida, igualmente, a manter a forma jurídica. Somente partindo desse momento fun- 
damental é que se pode compreender porque toda uma série de outras relações sociais reveste a forma jurídica. (Pasukanis, apud Sartori, 2010, p. 109; grifos meus)

A partir de perspectiva semelhante, Lukács destacou como os processos de circulação de mercadorias vieram a favorecer, ao longo da história do ser social burguês, o surgimento de sistematizações e reflexões teóricas e doutrinárias abstratas e gerais que serviram para a regulação das trocas comerciais e para a produção capitalista em geral.

O filósofo húngaro consegue então capturar, pela análise, as contradições fundamentais que se estabelecem no interior da economia - enquanto expressão de teleologias primárias, como vimos - e do direito - expressão clara de teleologias de tipo secundário - bem como na relação entre essas duas esferas de objetivação do ser social. Nesse processo, o direito vai se revelando também como elemento mistificador das reais formas antagônicas das relações sociais no mundo burguês e até como indutor de novas mistificações. É do processo de equalização de relações entre desiguais, que ocorre na troca mercantil, que Lukács, segundo Sartori, extrai a ambiguidade do conceito de justiça no mundo burguês. O filósofo húngaro capta toda a complexidade desse processo e, segundo Sartori, chega a apontar o direito como um dos sustentáculos da desigualdade em qualquer sociedade que não rompa com a forma de propriedade privada (ou estatal) dos meios de produção. O resgate da reflexão luckasciana contribui, portanto, para a desmistificação daquela visão segundo a qual o direito poderia ordenar e coordenar interesses conflitantes que se manifestam na vida social. O que aparece, então, com todas as suas nuances, é a característica que o direito e o ordenamento jurídico adquirem, ao longo do desenvolvimento do ser social, de tornarem-se escoras complexas de uma ordem societária injusta - e ela mesma reprodutora de desigualdades fornecendo-lhe uma aparência de igualdade. ${ }^{6}$

6. “[...] o Direito não é burguês simplesmente por servir aos interesses burgueses, mas sim por estar indissociavelmente conectado com a gênese e com a manutenção da sociedade civil burguesa (e com a própria forma mercantil). Sua configuração, com a correlata noção de igualdade jurídica, permanece nos limites burgueses, ou seja, da sociedade civil-burguesa, mesmo após a expropriação dos exploradores. Isso significa que, mesmo na 'transição ao modo de produção socialista', haveria a configuração de desigualdade, pois o direito perpetua sua forma após a mudança nominal de proprietário dos meios de produção, sendo, portanto, como todo o direito, o direito de desigualdade. Configura-se, assim, enorme engano entender-se socialista uma sociedade que transfere juridicamente (ou seja, 'com os limites aqui enumerados') a propriedade dos meios de produção à coletividade” (Sartori, 2010, p. 114). 
Mas falar em reprodução das relações sociais na sociedade capitalista é falar em contradições e antagonismos, o que nos leva, já de início, à consideração de que o direito, também ele, é atravessado por essas negatividades e torna-se reprodutor mesmo dessas relações. Por isso é muito importante resgatar como Lukács, ao afirmar o conteúdo de classe do direito, não deixa de apontar o complexo de processos contraditórios que, justamente por isso, esse direito carrega em seu interior, o que oportuniza a problematização de sua aparente neutralidade. O filósofo húngaro reafirma, sobretudo, que nenhum desses processos decorre de qualquer teleologia estranha ao mundo dos homens: antes resultam da práxis concreta do ser social e por eles podem ser também transformados.

Nesse sentido, embora o direito seja um direito de classe — vale dizer, de classe dominante - , esse conteúdo de classe não pode ser apartado do complexo social total e das mediações que surgem permanentemente em seu interior, a partir das negatividades que se impõem. E nosso autor faz notar, nesse processo, que as abstrações próprias do direito garantem que princípios como liberdade, dignidade etc., convivam com aqueles que são próprios da sociedade que é regida pelo valor de troca e pelo trabalho assalariado - como competição e impessoalidade, por exemplo.

Segurança jurídica e "imparcialidade" são valores muito caros à necessidade de reprodução da sociedade regida pelo capital. Cumprem um papel fundamental na construção de uma aparência fetichizada ou até reificada de relações de desigualdade que não podem aparecer enquanto tais. E todos os intrincados processos societários que subjazem ao direito e ao universo jurídico têm que ficar subsumidos para que ele possa cumprir suas funções na sociedade e inserir-se na vida normal de todos os homens. O fato de aparentemente ser uma esfera autossuficiente, e que apenas especialistas podem dominar seus códigos e linguagem, tem a ver precisamente com aquilo que Lukács identificou e nomeou como o "novo fetichismo":

O novo fetichismo [...] consiste no fato de que o Direito é tratado [...] como um campo fixo, compacto, determinado com univocidade "lógica" e, desta forma, é objeto de pura manipulação não somente na práxis, mas também na teoria, onde é entendido como um complexo fechado na própria imanência, autossuficiência, acabado em si, que apenas é possível manejar corretamente mediante a lógica jurídica. (Lukács, apud Sartori, 2010, p. 96) 
Autonomia, especialistas e instituições que o sustentam também fazem parte das requisições básicas para que o direito possa existir na sociedade de desiguais e que produz cotidianamente a desigualdade.

O fato de o direito ter um caráter de classe e de ser sustentado por um Estado, também ele dominado por interesses de classe majoritárias, tem as maiores consequências na vida das pessoas, principalmente quando "julgadas" por algum "crime", ou por algum ato ilícito, pois elas estarão, no limite, à mercê dessa discricionariedade de classe, ainda que isso se dê com muitas e complexas mediações.

Mas é importante reafirmar que o direito não é algo monolítico, constituído por tendências unilineares que apontam em uma única direção de dominação classista; pelo contrário, é um processo social permeado de contradições — embora pretendendo-se isentas delas. Nas palavras de Lukács,

O funcionamento do Direito positivo se apoia [...] sobre o seguinte método: manipular um turbilhão de contradições de modo tal que dele surja um sistema, não só unitário, mas também capaz de regular praticamente, tendendo ao ótimo, o contraditório acontecer social, de sempre se mover com elasticidade entre polos antinômi$\cos [\ldots]$, a fim de sempre reproduzir — no curso de contínuas alterações do equilíbrio no interior de um domínio de classes em lenta ou rápida transformação — as decisões e os estímulos às práticas sociais mais favoráveis àquela sociedade. (Lukács, apud Sartori, 2010, p. 115; grifos meus)

Em outros termos, o direito é também permeável à atuação das forças que pretendem nele incidir em busca de novos ordenamentos das relações sociais, e não só à manutenção do estado de coisas. É o que abordaremos no item sobre a justiciabilidade dos direitos sociais.

Mas antes é preciso responder à questão inicial: qual é, então, a melhor forma para referirmo-nos ao Serviço Social quando o assistente social atua na interface com o jurídico e com o direito?

2.3 Afinal, Serviço Social no "campo" ou na "área" sociojurídica (ou "jurídico-social")?

À luz de toda a reflexão precedente, proponho que, em vez de "campo sociojurídico" ou "jurídico-social”, adotemos a terminologia área sociojurídica. 
Justifico: em primeiro lugar, não seria "campo", naquele sentido de Bourdieu, porque não estamos disputando (corporativamente) com magistrados, promotores ou advogados, nesse espaço ou nessa área, o direito de dizer o direito (ainda que seja o direito social!). Antes, é preciso ver tais operadores ou especialistas do direito como trabalhadores que, tal qual os assistentes sociais, psicólogos, educadores etc., estão subordinados à mesma lógica do assalariamento de suas atividades, ainda que com diferenças bastante acentuadas (que têm a ver com aquilo que Lukács e Engels observaram sobre os "especialistas" do direito), que vale a pena a qualquer momento aprofundar pela análise.

O que está dado como desafio e possibilidade aos assistentes sociais que atuam nessa esfera em que o jurídico é a mediação principal — ou seja, nesse lócus onde os conflitos se resolvem pela impositividade do Estado - é trazer aos autos de um processo ou a uma decisão judicial os resultados de uma rica aproximação à totalidade dos fatos que formam a tessitura contraditória das relações sociais nessa sociedade, em que predominam os interesses privados e de acumulação, buscando, a cada momento, revelar o real, que é expressão do movimento instaurado pelas negatividades intrínsecas e por processos contraditórios, mas que aparece como "coleção de fenômenos" nos quais estão presentes as formas mistificadoras e fetichizantes que operam também no universo jurídico no sentido de obscurecer o que tensiona, de fato, a sociedade de classes.

A partir das expressões cotidianas mais singulares e aparentemente desprovidas de mediações sociais concretas é que os assistentes sociais que atuam nessa área têm que operar e trabalhar para reverter a tendência reprodutora da dominação, da culpabilização dos indivíduos e da vigilância de seus comportamentos.

Em resumo: se o direito — que só surge quando também se completam os requisitos históricos para o surgimento da sociedade de classes - é um dos sustentáculos de uma ordem produtora e reprodutora de desigualdades, ele também tem em suas entranhas um incessante movimento de contrários. E para não esquecer as certeiras lições de Iamamoto a respeito do significado social de nossa profissão, é justamente por isso que o Serviço Social pode operar no universo jurídico, optando por fortalecer um ou outro polo dessas contradições, tema do próximo item de nossa reflexão.

Em segundo lugar, vejo que a prioridade ontológica aqui é do "social", e não do "jurídico", uma vez que as teleologias primárias que põem a questão social como expressão da luta de classes - ou, mais precisamente, as disputas permanentes do 
capital contra o trabalho na busca de maior exploração, e do trabalho contra capital na resistência a esse processo de exploração (e tudo que daí recorre) -, essa luta, esse conflito é que põe ao ser social a necessidade da instituição de teleologias secundárias, como o direito, o universo jurídico e a política, conforme já vimos.

Assim, sociojurídico expressa com mais precisão do que jurídico-social o que o Serviço Social quer nominar como espaço onde se põem demandas que têm uma especificidade histórica em relação a outras áreas. Vale dizer: justamente porque a questão social é a expressão da luta de classes, da alienação do trabalho, da necessidade que o capital tem de manter a propriedade privada (que, essa sim, é uma categoria jurídica) etc., e que gera o movimento da história e de todas as demais objetivações do ser social no mundo burguês, ela tem prioridade ontológica em relação às objetivações que se plasmam a partir de teleologias secundárias como o direito e a política.

Por entender o "social" - ou essa partícula sócio — como expressão condensada da questão social, e dela emanarem continuamente as necessidades que ensejarão a intervenção de juristas, especialistas do direito, de agentes políticos e seus partidos etc., assim como, por ser espaço contraditório no qual os assistentes sociais atuam — buscando defender tanto o projeto ético-político da profissão como seus direitos como trabalhadores - é que defendo que passemos a utilizar a expressão Serviço Social na área sociojurídica.

Assim, em termos sintéticos e simples, pode-se dizer que o trabalho do assistente social na área sociojurídica é aquele que se desenvolve não só no interior das instituições estatais que formam o sistema de justiça (Tribunais de Justiça, Ministério Público e Defensorias), o aparato estatal militar e de segurança pública, bem como o Ministério de Justiça e as Secretarias de Justiça dos estados, mas também aquele que se desenvolve nas interfaces com os entes que formam o Sistema de Garantias de Direitos (cf. Conanda, 2006) que, por força das demandas às quais têm que dar respostas, confrontam-se em algum momento de suas ações com a necessidade de resolver um conflito de interesses (individuais ou coletivos) lançando mão da impositividade do Estado, ou seja, recorrendo ao universo jurídico.

Nesse sentido, a existência da lide, que significa "pretensão resistida" (cf. Delfino, 2013) e de um processo judicial (seja ele civil, criminal, penal ou da área dos direitos da infância e juventude e dos relativos aos direitos humanos e aos direitos sociais) é um demarcador quase que obrigatório para considerarmos que se está em face ou não do universo sociojurídico. Assim, tanto o assistente social que atua em uma instituição de acolhimento de crianças e adolescentes, que estão sob a medida 
protetiva de acolhimento institucional (um abrigo), como aquele que atua em uma Vara de Infância, ou em uma Defensoria Pública, estará atuando no universo sociojurídico ou na interface com ele. Isso é fácil de perceber.

Também os assistentes sociais que atuam como agentes fiscais nos Conselhos de Fiscalização Profissional (conjunto CFESS/Cress) e em suas diretorias fazem parte do universo sociojurídico, uma vez que os conselhos profissionais são tribunais de ética e têm o poder de determinar juridicamente (ou seja, pela impositividade do Estado) quem pode ou não exercer a profissão de assistente social ou se deve ter esse exercício suspenso ou não por força de decisão emanada dos julgamentos éticos, à luz das legislações pertinentes. Mais complexo é delimitar até que ponto os assistentes sociais que estão atuando nos Centros de Referência em Assistência Social (Cras) e/ou nos Centros Especializados de Referência em Assistência Social (Creas) estariam atuando também nas fronteiras desse universo.

Pode-se dizer, sem medo de errar, que dependerá de cada caso. Os casos que são atendidos no âmbito da política de assistência social e até da saúde podem, sim, ter interface com essa área. Basta pensar em um caso de violência doméstica ou abuso sexual de criança que vai ser atendido por profissionais de toda a rede de proteção de direitos, ou em um caso de proteção pela Lei Maria da Penha. Enquanto aquele caso estiver "judicializado", ou constituir-se em uma lide ("pretensão resistida", conforme vimos anteriormente), pertencerá ao universo sociojurídico. Ou seja, sua resolutividade, além de todas as iniciativas de proteção social e psicológica, também será tributária de uma decisão judicial.

Após ter demarcado minimamente essas fronteiras, cabe apontar, ainda que brevemente, o potencial que está reservado aos assistentes sociais nessa área.

\section{Judicialização das expressões da questão social e justiciabilidade dos direitos sociais no Brasil: espaço importante para o trabalho de assistentes sociais que atuam no sociojurídico}

Vários autores têm se debruçado sobre a tendência, que vem se desenvolvendo nos últimos anos no Brasil, de se levar ao Poder Judiciário, ou à área jurídica, centenas e milhares de casos que poderiam, ou deveriam, ser respondidos no âmbito da esfera política. 
Alguns deles mostram que após as importantes conquistas trazidas pela Constituição de 1988 (também ela fruto de grandes embates sociais, como sabemos), instalou-se uma forte tendência neoliberal de desmonte e contrarreformas do Estado, fazendo com que as políticas não fossem capazes de atender às demandas societárias e aos quesitos de proteção de direitos sociais determinados pela Constituição. Tampouco o movimento social e os sindicatos, centrais sindicais e entidades representativas dos trabalhadores tiveram força suficiente para fazer valer esses direitos para amplas parcelas da população brasileira.

Tal panorama levou a que o Poder Judiciário passasse a ser o depositário das demandas sociais dos segmentos mais fragilizados e subalternizados da sociedade, na busca de fazer valer os direitos sociais trabalhistas, de proteção de crianças, idosos etc. Ou seja, aquilo que pela pactuação política não está sendo possível conquistar em nosso país, desde Collor, Fernando Henrique, passando por Lula e agora Dilma - porque os interesses econômicos e financeiros das elites dominantes determinam claramente os rumos do Estado brasileiro - , está se buscando no Poder Judiciário, pois, sem muitas alternativas, a população não tem como reivindicar fácil acesso a direitos básicos de cidadania.

José Paulo Netto, em 1999, já apontava, em lúcida análise sobre o governo Collor, como o Estado estava sendo colocado a serviço dos reordenamentos impostos pelo projeto político do grande capital internacional, "subvertendo e negando a lógica constitucional de defesa de direitos" e levando a uma "inviabilização da alternativa constitucional da construção de um Estado com amplas responsabilidades sociais, garantidor de direitos sociais universalizados" (cf. Netto, 1999).

E também como outros autores, Beatriz Aguinsky e Ecleia Huff de Alencastro apontaram que, em todos os governos que vieram depois de Collor, as políticas sociais passaram a ser fragmentadas, focalizadas e a ter sérios problemas de financiamento, o que acabou por impedir sua implementação objetiva (cf. Aguinsky e Huff de Alencastro, 2006, p. 19-26). Por isso, os autores citados podem afirmar que ao mesmo tempo em que houve a ampliação dos direitos positivados na Constituição Federal de 1988, ocorreu sua negação em diferentes instâncias administrativas, o que acabou por gerar esse fenômeno na esfera pública, que é o que alguns juristas e cientistas sociais estão chamando de "judicialização dos conflitos sociais" ou, ainda, "judicialização da política".

Tal fenômeno, segundo Aguinsky e Huff de Alencastro (Idem), caracteriza-se pela transferência, para o Poder Judiciário, da responsabilidade de promover o enfrentamento à questão social, na perspectiva de efetivação dos direitos humanos. 
Argumentam as autoras que a profunda e persistente deslegitimação do Estado como esfera de proteção social dos mais subalternizados fez com que o Poder Judiciário ou o sistema de justiça como um todo passasse a ser procurado por esses segmentos para que os direitos e atributos de cidadania sejam efetivados. Alguns pesquisadores chegam a afirmar que o enfraquecimento da política e das esferas de resolução pública dos conflitos e das reivindicações sociais, e o fato de o próprio Poder Executivo muitas vezes se colocar como violador de direitos por seus atos ou omissões perante a ganância do capital, fez com que a sociedade passasse a incumbir o Judiciário da tarefa de possibilitar a efetivação dos direitos sociais.

Pertinente, então, parece ser a definição de judicialização, dada por Aguinsky e Huff de Alencastro, como a "tendência em curso de transferir para um poder estatal, no caso do Judiciário, a responsabilidade de atendimento, via de regra individual, das demandas populares - coletivas e estruturais, nas quais se refratam as mudanças do mundo do trabalho e as expressões do agravamento da questão social - em vez de fortalecer a perspectiva de garantia de direitos positivados, [o que] pode contribuir para a desresponsabilização do Estado, sobretudo dos poderes Legislativo e Executivo, com a efetivação desses direitos, através de políticas públicas" (Aguinsky e Huff de Alencastro, 2006, p. 25).

Face perversa da judicialização dos conflitos da sociedade brasileira é também a crescente onda de encarceramento de pessoas pertencentes aos extratos mais vulnerabilizados da população (e cada vez mais jovens), bem como os apelos midiáticos pelo recrudescimento das penas e pela transformação de delitos comuns em crimes hediondos; isso para não falar da forte campanha pela redução da idade penal. Alguém já denominou tal processo como próprio de uma era na qual impera um "populismo punitivo". Nunca como hoje as "prisões da miséria" (na lúcida caracterização de Löic Wacquant) estiveram tão abarrotadas. E pior: desde Washington, com sua política de tortura para obter confissões na luta "contra o terrorismo", e a administração forçada de alimentos a presos em greve de fome em Guantânamo, até a criminalização dos movimentos sociais em várias partes do mundo, assiste-se a uma regressão brutal nas tentativas de implementação das proteções lastreadas no direito dos direitos humanos.

Nesse passo de nossa reflexão é pertinente abordar também o fato de que direito e lei não se confundem, sendo o primeiro sempre muito mais amplo e complexo do que a própria lei ou do que as estruturas burocráticas que se formaram para garantir seu cumprimento. Como bem coloca Wanderlino Nogueira Neto, o direito origina-se sempre nas relações sociais (ou "na rua") e só posteriormente é 
que é objetivado em leis. Tal dinâmica supõe, inclusive, a possibilidade de questionamento do próprio direito que foi cristalizado em uma lei. Em outros termos, é esse processo que possibilita a negação de vigência de uma lei, "colocando-a como contrária ao Direito" (Nogueira Neto, 2012, p. 30-31).

Mas outro aspecto da judicialização das expressões da questão social que também ganha bastante importância na atualidade é o chamado "controle judicial das políticas públicas". Essa tendência vem se desenvolvendo com força e diz respeito às iniciativas da sociedade civil organizada para cobrar judicialmente que o Poder Executivo cumpra com o seu dever de implementar ações previstas nas legislações orçamentárias que destinam recursos às políticas sociais de proteção à infância e adolescência, deficientes, velhice, contra a violência doméstica etc. Tal alternativa é complexa porque envolve a chamada "separação dos poderes" e as vedações constitucionais de interferência de um poder sobre outro, e vem ganhando cada vez mais relevância em nossa sociedade, principalmente nessa quadra histórica em que se está diante da omissão do Estado ou do não cumprimento de preceitos constitucionais que dispõem sobre aspectos vitais à existência dos indivíduos e grupos vulnerabilizados. Nesse processo, verifica-se que as cortes de justiça têm sido cada vez mais pressionadas a se pronunciar sobre casos em que governantes vetam artigos de leis ou praticam atos que ferem preceitos fundamentais que garantiriam recursos financeiros mínimos às políticas sociais (saúde, educação etc.). É o que ocorre, por exemplo, quando governantes vetam leis orçamentárias (cf. Nogueira Neto, 2012, p. 39-41).

Assim, tem-se, neste campo do controle jurisdicional das políticas públicas - ou naquele que Piovesan e Vieira (2013) chamam de justiciabilidade dos direitos sociais - um enorme potencial de trabalho para os assistentes sociais, que podem oferecer importantes subsídios às decisões dos tribunais de justiça para a efetivação de direitos de amplas parcelas da população que foram alijadas do acesso aos bens produzidos socialmente ao longo de séculos de dominação burguesa no País. Como bem coloca Wanderlino Nogueira Neto (2012, p. 45),

“[...] nessa fronteira com as políticas públicas sobressaem os hard cases, na expressão de Ronald Dworkin, que pedem, para sua solução, argumentos firmados em paradigmas ético-políticos [...] e na alta sensibilidade judicial e no seu comprometimento com os direitos humanos, com o desenvolvimento humano autossustentado e com a democracia".

Como abordei linhas atrás, há uma enorme contradição no capitalismo entre o sistema produtivo e a organização estatal e jurídica das relações sociais, gerando-se 
no interior desta contradição inúmeras outras, que acabam sendo o húmus para o trabalho de um assistente social quando este se coloca na direção ética e política da ampliação e concretização de direitos, e não no fortalecimento do polo da "responsabilização criminal". Em outros termos, o âmbito daquilo que Piovesan e Vieira denominam de justiciabilidade dos direitos sociais pode ser considerado um espaço privilegiado para a atuação do assistente social hoje. Basta observar, por exemplo, o manancial de contradições que surgem no cenário jurídico a partir do momento em que o movimento social fez insculpir no texto da Constituição Federal o famoso artigo $6^{\circ}$, que trata dos direitos sociais. ${ }^{7}$ De fato, esse é um dos artigos mais importantes da Constituição para os assistentes sociais em seu trabalho cotidiano, uma vez que é o que permite a exigibilidade daquilo que deve ser considerado prioritário nas políticas públicas e que até oferece os argumentos concretos sobre a necessidade de construção de uma nova organização societária.

Diferente do que ocorre com direitos civis e políticos, a arena da exigibilidade dos direitos sociais é aquela em que o universo jurídico tem que buscar soluções políticas e administrativas que, ao fim e ao cabo, questionam as formas de acumulação, bem como acirram as disputas pelo fundo público. É como se o artigo $6^{\circ}$ tivesse o potencial de deslocar os cidadãos que hoje se encontram na fila dos réus (como devedores, ladrões de baixa periculosidade e pequenos traficantes etc.) para a fila dos requerentes de direitos perante o Estado. É também o artigo que permite aos assistentes sociais contribuírem com promotores de justiça e defensores públicos para que estes façam, perante as cortes, a denúncia daquilo que Canotilho chamou da "ditadura do caixa vazio".

Em resumo, temos que com a Constituição de 1988, com o capítulo dos direitos sociais e também das novas funções do Ministério Público, bem como com a criação de novas ações jurídicas, ${ }^{8} \mathrm{o}$ assistente social que atua nessa área ganha a possibilidade de "dar os argumentos concretos e tangíveis àqueles que vão, no interior do universo jurídico e no curso dos processos judiciais, "dizer o direito social" (cf. Piovesan e Vieira, op. cit.).

A Constituição de 1988 trouxe também aos assistentes sociais da área sociojurídica a possibilidade de demonstrarem, com dados concretos extraídos de estudos sobre a realidade de cada município onde vivem os cidadãos, das prisões onde estão

7. Os direitos sociais previstos no artigo $6^{\circ}$ da Constituição Federal de 1988 são: educação, saúde, alimentação, trabalho, moradia, lazer, segurança, previdência social, proteção à maternidade e à infância, assistência aos desamparados.

8. Como a de Arguição de Descumprimento de Preceito Fundamental, por exemplo. 
encarcerados, ou das instituições que têm que defendê-los - e, principalmente, do contato cotidiano com a população que é alvo ou credora da Justiça -, como o não cumprimento dos preceitos fundamentais da Constituição lesam a vida e os direitos de parcelas significativas da sociedade. Mas para isso é preciso que haja assistentes sociais conscientes de seu papel. Profissionais que sejam bem formados do ponto de vista crítico analítico e que se disponham a perguntar insistentemente por que o universo jurídico tende a ser mais eficaz e célere quando se trata de defender o direito constitucional à propriedade e não apresenta a mesma celeridade e assertividade no que diz respeito ao direito à dignidade e à proteção física e moral de condenados, com relação à tortura e maus-tratos nas prisões, por exemplo? Afinal, ambos - o direito à propriedade $\mathrm{e} o$ direito do cidadão de não ser agredido pelo Estado que deveria proteger sua integridade quando sob sua custódia —, são iguais na esfera dos direitos fundamentais consagrados no Capítulo 5 da Constituição.

\section{Alguns desafios da intervenção dos assistentes sociais na interface com o Direito e com o universo jurídico}

O Serviço Social brasileiro construiu, nos últimos trinta anos, um projeto profissional que o coloca em uma perspectiva de resistência à exploração capitalista. Um projeto que tem potencial para capacitar os profissionais para um desempenho qualificado nos diversos campos onde atua, iluminando-os para que articulem suas ações cotidianas a sujeitos coletivos que também se mostrem empenhados tanto no acesso a direitos como na busca da construção de outra ordem societária. Esse projeto contém um conjunto de referências técnicas, teóricas, éticas e políticas para o exercício profissional, e está lastreado na perspectiva crítica e ontológica de análise da realidade social, tendo como pressuposto que a sociedade burguesa gera limites intransponíveis para se alcançar a real emancipação do ser social.

Mas no interior desse mesmo projeto há o reconhecimento de que as lutas por direitos e pela democratização radical das formas de exercício do poder político têm considerável potencial para a resistência à barbarização imposta pelo capitalismo em sua fase atual, bem como podem contribuir para o avanço de propostas coletivas que busquem uma nova organização societária.

A profissão viveu, nas três últimas décadas, um rico movimento teórico e político que plasmou interpretações competentes e elucidativas acerca de inúmeros 
temas de interesse para a sociedade e para outras áreas de produção do conhecimento próximas ao Serviço Social. É assim que ela tem hoje uma interlocução profícua e instigante com a Psicologia, com as Ciências Sociais em geral, com a Educação, $\mathrm{e}$, notadamente, com o universo jurídico (principalmente no que tange às questões de efetivação de direitos de crianças e adolescentes, idosos, mulheres etc.), bem como com as várias profissões do campo da Saúde e da Assistência Social.

Um dos elementos propiciadores desses avanços (não o único, obviamente) foi a elucidação do significado social da profissão no mundo burguês, por meio das seminais análises de Marilda Iamamoto que, já à partida, advertia-nos de que $o$ significado social da profissão só poderia ser profunda e verdadeiramente apreendido se a análise fosse capaz de integrar e, ao mesmo tempo, ultrapassar os elementos internos do Serviço Social, ou seja — sua trajetória histórica, a ação dos profissionais nos diversos campos de atuação, os parâmetros legais que construiu etc. - , situando-o no contexto da totalidade social e das relações mais amplas que o condicionam. Segundo a autora, foram essas relações que, afinal, acabaram atribuindo ao Serviço Social particularidades em relação a outras profissões. Em outros termos, Iamamoto mostrou-nos que, para compreender o que é e como se desenvolveu o Serviço Social enquanto profissão -, ou seja como atividade assalariada, com competências específicas e atribuições privativas, e cujos profissionais são requisitados por instituições, empresas ou organizações em geral —, era preciso entender, primeiramente, como se dá o processo que Marx denomina produção e reprodução das relações sociais no mundo burguês, uma vez que a profissão é impensável sem a inserção nessas relações.

Foi assim, pois, que Marilda observou que, além de o movimento de reprodução do capital recriar continuamente a apropriação do trabalho excedente sob a forma da mais-valia, ele cria e reproduz, em escala ampliada, os antagonismos das relações sociais por meio das quais efetiva-se a produção. Nesse mesmo processo, segundo Iamamoto,

[...] reproduz-se a contradição entre igualdade jurídica de livres proprietários, e a desigualdade econômica que envolve a produção social, contraposta à apropriação privada do trabalho alheio, ou seja, recriam-se os antagonismos dessas relações e o véu ideológico que as envolve, encobrindo sua verdadeira natureza. (Iamamoto, 2007, p. 253)

Após ressaltar, então, que a criação de uma superpopulação trabalhadora sempre disponível para ser recrutada — faz parte da particularidade do regime 
capitalista e que os salários dos trabalhadores ficam à mercê da regulação desfavorável a seus interesses (justamente em virtude da existência daqueles trabalhadores sobrantes), Iamamoto mostra que é a partir dessa factualidade ontológica que se consubstancia a questão social no mundo burguês.

Assim, uma parcela significativa dos assistentes sociais brasileiros desenvolveu a compreensão de que a questão social não é apenas a expressão da pauperização relativa da classe trabalhadora sob o domínio do capital, significando, principalmente, o conjunto de reivindicações dos trabalhadores por seus direitos e pelo seu reconhecimento enquanto classe. Ela é também a expressão da intermediação do Estado nessas relações conflituosas que se estabelecem entre trabalhadores e empresariado. Nesse cenário, como já colocado anteriormente, o Estado e suas instituições que formam o Poder Judiciário, o Poder Executivo e o Legislativo passa a ter um papel fundamental na regulação das relações sociais antagônicas próprias do mundo burguês. ${ }^{9}$

É então, nesse complexo de determinações, em cujo centro opera a mediação do Estado capturado pelo capitalismo monopolista, que Iamamoto localiza a gênese e o significado do Serviço Social como uma profissão que - inscrita na divisão social e técnica do trabalho, e tendo como "matéria-prima" as expressões da questão social —, se integra "ao processo de criação das condições indispensáveis ao funcionamento da força de trabalho e à extração da mais-valia", embora não participe diretamente da produção de mercadorias e do valor (Iamamoto, 2007, p. 256).

Por estar inserido e por ser fruto mesmo dessas relações entre o capital e o trabalho, e participar das respostas que o Estado e a sociedade têm que dar aos antagonismos de classe, o Serviço Social também adquire um caráter eminentemente contraditório. E com essas análises Iamamoto alcançará todas as premissas que lhe permitiram formular o que chamei, em outro lugar, de a Grande tese (ver Borgianni, 2008):

Como as classes sociais só existem em relação, pela mútua mediação entre elas, a atuação do assistente social é necessariamente polarizada pelos interesses de tais classes, tendendo a ser cooptada por aqueles que têm uma posição dominante. Reproduz,

9. Iamamoto descreveu esse processo de forma cristalina já no início dos anos 1980: “O Estado passa a intervir diretamente nas relações entre empresariado e a classe trabalhadora, estabelecendo não só uma regulamentação jurídica do mercado de trabalho, através da legislação social e trabalhista específicas, mas gerindo a organização e a prestação dos serviços sociais, como um novo tipo de enfrentamento da questão social” (In: Iamamoto e Carvaho, 1982, p. 77). 
também, pela mesma atividade, interesses contrapostos que convivem em tensão. Responde tanto a demandas do capital como as do trabalho e só pode fortalecer um ou outro polo, pela mediação de seu posto. Participa tanto dos mecanismos de dominação e exploração como, ao mesmo tempo e pela mesma atividade, de respostas a necessidades de sobrevivência da classe trabalhadora e de reprodução dos antagonismos desses interesses sociais, reforçando as contradições que constituem o móvel da história. A partir dessa compreensão é que se pode estabelecer uma estratégia profissional e política para fortalecer as metas do capital ou do trabalho, mas não se pode excluí-los do contexto da prática profissional, visto que as classes só existem inter-relacionadas. É isso inclusive que viabiliza a possibilidade do profissional colocar-se no horizonte dos interesses das classes trabalhadoras. (Iamamoto, in Iamamoto e Carvalho, 1982, p. 75; grifos meus)

Essa afirmação do caráter contraditório do exercício de qualquer assistente social foi a contribuição maior à compreensão dos reais desafios que estão colocados aos profissionais em sua prática cotidiana. De fato, ela expressa um divisor de águas em relação a análises que se fixam em unilateralidades ou em posições voluntaristas. Essa constatação ontológica tem o potencial de mostrar a qualquer profissional que sua ação pode tanto favorecer os interesses do capital quanto os do trabalho, pode reforçar iniciativas conservadoras, porque coladas à imediaticidade das relações alienadas, ou buscar resistir e romper com as formas autoritárias, desumanizadas e antidemocráticas que brotam continuamente do solo burguês, seja em uma instituição, seja em uma organização não governamental, ou na assessoria a movimentos sociais.

Daí também decorre o caráter essencialmente político da ação profissional, "uma vez que ela se explica no âmbito das próprias relações de poder da sociedade" (Yazbek, 1999, p. 91).

Naturalmente, a possibilidade de a profissão colocar-se na perspectiva do reforço dos interesses da população trabalhadora, com a qual atua, depende mais de um projeto profissional coletivo do que da volição individual dos assistentes sociais. É esse projeto que pode orientar permanentemente as ações dos profissionais em seus diversos campos de trabalho.

Assim, pode-se afirmar que a partir dessas contribuições que iluminam ou fornecem os elementos fundamentais a partir dos quais os assistentes sociais podem fazer a crítica ontológica das contradições sociais que se expressam em seu cotidiano, é possível e necessário fazer a análise de como a profissão vem se desenvolvendo e delineando nos diversos espaços sócio-ocupacionais, incluídos os que 
pertencem à área sociojurídica. Essa tarefa é urgente para todos nós que partilhamos do projeto ético-político da profissão e supõe enorme esforço teórico para captar as complexas determinações que aí comparecem. Evidentemente, não tenho a menor pretensão de aqui dar conta nem mesmo do começar essa tarefa. Alguns assistentes sociais já iniciaram estudos que poderão potencializar muito nossos conhecimentos das especificidades próprias desse espaço de intervenção profissional (ver, especialmente, Fávero, 1990; Colmán, 2004; Alapanian, 2008; Torres, 2005; Dahmer, 2012; Tejadas, 2012).

É necessário e urgente pesquisar a gênese e os processos de criação e reprodução do Serviço Social em todos os espaços sócio-ocupacionais que formam o universo sociojurídico (sistema prisional, ministério público, defensorias, sistema socioeducativo, tribunais de justiça etc.), para conhecer, de fato, o que está se passando aí em seu interior e se possa avançar em propostas coerentes ou que expressem nosso projeto ético-político a partir da "análise concreta de situações concretas".

Aqui, o que posso então é apenas apontar, à luz dos fundamentos precedentes, alguns dos desafios cruciais com os quais os assistentes sociais se deparam nessa área.

Inicialmente, destacaria o universo de questões que se põem aos profissionais que atuam no interior das instituições do sociojurídico, pelo simples fato de, como visto, o jurídico configurar-se como a esfera de resolução dos conflitos pela impositividade do Estado. São questões de ordem ética e política que surgem nesse universo e das quais não se pode "escapar", sendo necessário enfrentá-las com coerência. Contribui para alargar esse desafio a crescente criminalização da pobreza e a judicialização das expressões da questão social. Tais determinações se impõem hoje no cotidiano profissional nas prisões, nos tribunais, nas unidades de internação de adolescentes, de forma avassaladora. Têm também expressão objetivada em todo um novo marco legal de caris conservador e que é fruto de articulações de parte da sociedade civil que vê no encarceramento, no recrudecimento das penas e na redução da idade penal, as formas reificadas e fetichizadas de reparação das vítimas da crescente violência urbana que foi gerada no processo histórico de superexploração do trabalho e concentração de poder e renda nas mãos de uma elite minoritária numericamente, mas poderosíssima econômica e politicamente.

Já o aviltamento mercantil que atingiu o ensino superior no Brasil nas últimas décadas pode provocar verdadeira tragédia profissional no desempenho que é exigido dos assistentes sociais nessa área que lida diretamente com os destinos das 
vidas das pessoas. De fato, nessa área, decide-se se alguém vai ser privado de liberdade, ou se vai perder a guarda de um filho, se vai poder ou não adotar uma criança ou conviver com um idoso.

Essa é uma esfera muito diferente daquela que é própria da execução das políticas sociais. A começar pelo fato de que na área sociojurídica não se trabalha contando com a mediação dos benefícios socioassistenciais. A mediação, via de regra, passa pelas interpretações que os profissionais fazem de problemas, situações e conflitos que estão judicializados, portanto aguardando uma decisão judicial, e não uma decisão ou um encaminhamento administrativo ou político. Nessas instituições do sociojurídico, como bem notou Colmán, o assistente social depara-se com demandas que "são apresentadas de forma individualizada, como conflitos entre partes, com litígios, cabendo [ao Judiciário] aplicar as leis existentes, estabelecendo as punições cabíveis e encaminhando soluções para as situações de conflito" (Alapanian, 2008, p. 16). E aqui já podemos demarcar uma primeira armadilha ou desafio que se põe ao assistente social em seu cotidiano: superar a aparência dos fenômenos com os quais vai trabalhar; tal aparência é a de problemas jurídicos, pois, como vimos, na realidade também carregam conteúdos de cunho eminentemente político e social, e nessas outras esferas é que também deveriam ganhar sua resolutividade.

Por isso, não se pode perder de vista, nem por um instante, nesse cotidiano que tende a reiterar a aparência reificada da processualidade societária, que quem atua na área sociojurídica está confrontando o tempo todo com as contradições que surgem ou se renovam reiteradamente a partir da relação tensa entre as determinações próprias da sociedade que é regida pelo capital e o buscar da "justiça". Na definição oficial, por exemplo, como exposta por Edson Sêda, o Poder Judiciário é "um poder da República que só atua quando provocado em sua jurisdição, para resolver conflitos de forma definitiva. Nas hipóteses em que um juiz se manifesta, sua decisão deve ser cumprida, para que haja a estabilidade necessária à sociedade organizada e ao bem comum" (Sêda, 2007, p. 53; grifos meus).

Ora, evidentemente isso é apenas a face imediata e aparente do Poder Judiciário, aparência que se desvanece quando começamos a pesquisar seu real significado na sociedade burguesa. O que o Poder Judiciário resolve "de forma definitiva" não são os problemas das pessoas ou da sociedade em geral, mas problemas e questões jurídicas, o que é muito diferente.

A chamada "tutela jurisdicional" protege bens jurídicos, que são mediações criadas socialmente e representam aquilo que uma sociedade definiu que deve ser 
protegido pela lei e pela coercitividade do Estado. Por exemplo, assim como o bem jurídico protegido pela criminalização do homicídio é a vida, o bem jurídico protegido pela criminalização do roubo é a propriedade. E esses dois "bens" são de naturezas essencialmente diferentes. Sem o primeiro, não há nenhuma relação social, pois a vida, obviamente, tem prioridade sobre qualquer outra determinação para o ser social; mas a segunda, a propriedade, é apenas e tão somente uma criação humana, uma abstração jurídica. A propriedade é um bem jurídico do mundo burguês.

Porém a "propriedade" não pode ser atingida ou fragilizada porque faz parte da sustentação da ordem natural criada pelas relações burguesas de produção. Por isso é que a lei, no caso dos conflitos fundiários, ao fim e ao cabo, acaba protegendo sempre a propriedade, e não necessariamente o proprietário. Isso porque a propriedade aqui adquire um papel muito mais importante do que apenas o de ser o direito de usufruto de um bem por alguém. Ela significa condição de existência de uma relação social de exploração de homens sobre outros homens. Mesmo que, em alguns casos, busque-se até argumentar pela função social da propriedade, será aquele outro sentido dela que prevalecerá sempre. Vê-se isso na maioria dos processos de desocupação de terrenos ocupados pela população carente de moradia.

Tendo isso consciente, nenhum assistente social poderia ter dúvidas, por exemplo, se fosse chamado a atuar em desocupações, de qual postura profissional e ética deveria ter. A justiça ou o universo jurídico "deixados a si mesmos" atuarão sempre nesse sentido: de restituir a "ordem das coisas", embora, como vimos, uma ordem produtora - e tendencialmente reprodutora de desigualdades. Se os homens e mulheres que adquirem consciência desse processo não atuarem no sentido de incrustar nele elementos de negatividade (resistências, oposições etc.), ele se moverá sempre nessa direção, e as mediações que serão produzidas serão sempre aquelas que servem à reiteração da ordem.

E aqui podemos apontar mais um dos desafios que estão postos para os assistentes sociais que atuam nessa área: a tendência de incorporarem, como sendo atribuição de sua profissão, ou de seu fazer profissional, os instrumentos de "aferição de verdades jurídicas", como o são o exame criminológico ou a inquirição de vítimas ou testemunhas, sob a eufemística ideia da "redução de danos".

E aí, nesses espaços nos quais vem imperando a lógica da judicialização das expressões da questão social e da criminalização das parcelas mais subalternizadas da população, o que tem que ser defendido como sendo próprio de nossa interven- 
ção é o estudo social (ver Fávero, 2003). O que é próprio de nossa intervenção é o estudo social, que, a partir de aproximações possíveis, deve buscar reproduzir as determinações que constituem a totalidade sobre a qual somos chamados a emitir um parecer técnico. Como já exposto, para essa reprodução ser o mais fiel possível, devemos ser capazes de capturar, pela análise, as mediações fundamentais que dão forma à realidade sobre a qual estamos pesquisando e as negatividades que lhe dão o movimento.

Esse trabalho de pesquisa em nada se assemelha à reprodução imediata e superficial do existente, ou à reprodução literal das palavras de um presidiário, que está sendo entrevistado por nós, ou de um casal que está em litígio pela guarda de um filho em uma Vara de Família. Por ser-nos demandado, nessa esfera, um estudo de situações complexas, nosso trabalho, também ele, torna-se de alta complexidade, o que, a bem da verdade, nos impediria de fazer um laudo ou um parecer a partir de um contato de vinte minutos com alguém. Mas em muitos locais é isso que nos está sendo exigido.

A armadilha está em o assistente social ir se tornando prisioneiro do possibilismo mais ordinário: se só é possível fazer isso, então vamos fazer, pois, caso contrário, o preso ficará sem um laudo e não poderá progredir de regime... $\mathrm{O}$ assistente social passa a considerar que aquilo é uma forma de "redução de danos".

É o mesmo raciocínio que se usa para justificar a atuação junto a crianças vítimas de violência sexual: para garantir que a criança não tenha que ser ouvida várias vezes sobre a violência sofrida, passo a admitir que ela seja ouvida de uma forma que também viola seus direitos e traz danos à sua vida psíquica, como vários especialistas já apontaram. E pior: contribuo para reforçar a visão de que a saída está no encarceramento dos pretensos agressores, em um cenário no qual a prisão só tem servido para tornar homens e mulheres muito piores do que quando entraram para o sistema prisional.

E aqui entramos em mais uma das armadilhas que estão postas no cotidiano de quem trabalha na esfera do chamado sistema de justiça: nessa área há um risco enorme de o assistente social deixar-se envolver pela "força da autoridade" que emana do poder de resolver as questões jurídicas pela impositividade, que é o que marca o campo sociojurídico, e "encurtar" o panorama para onde deveria voltar-se sua visão de realidade, deixando repousar essa mirada na chamada lide, ou no conflito judicializado propriamente dito; passando a agir como se fora o próprio juiz, ou como um "terceiro imparcial", mas cuja determinação irá afetar profunda- 
mente a vida de cada pessoa envolvida na lide. Por exemplo, em um processo em que alguém está sendo acusado de negligência para com uma criança, seja o pai ou a mãe: a decisão judicial buscará "recompor o direito da criança que foi violado", podendo, no limite, alijar ou esse pai ou essa mãe, ou ambos, do poder familiar sobre essa criança. $\mathrm{O}$ assistente social, diferentemente de um juiz ou de um promotor, diante de um caso assim, terá que olhar para a totalidade da problemática e suas consequências, e não só para a proteção dos direitos da criança que, sem dúvida, será o foco da atenção do juiz.

O mesmo ocorre quando estamos lidando com problemas relacionados a uma denúncia de abuso sexual. Para um juiz da área criminal, o que estará em seu foco de atenção será a reconstituição de uma verdade jurídica para a incriminação do suposto abusador. Por isso, para ele são tão importantes as provas. Já o foco de trabalho de um assistente social terá que ser muito mais amplo e profundo, para que possa atuar visando a proteção de direitos de todos os envolvidos. Sobre isso é importante ter contato com as pesquisas e a literatura especializada que já começa a surgir sobre o tema, principalmente aquelas que vêm discutindo de forma crítica os chamados depoimentos especiais, ou escutas especiais, de crianças vítimas de abuso sexual (ver AASPTJSP/Cress/9a Região, 2012; Azambuja, 2011), esta última uma importante promotora de Justiça que buscou seu doutoramento na área de Serviço Social para abastecer-se das reflexões realizadas em nossa área de conhecimento.

Deve-se chamar a atenção, ainda, para outro desafio que se põe no cotidiano dos assistentes sociais: ao assumir para si as demandas e as práticas institucionais sem questioná-las, apenas reproduzindo respostas fiscalizadoras dos comportamentos, e criminalizadoras dos sujeitos que são alvo da ação judicial, passam a não se ver, eles mesmos, como trabalhadores, e não participam dos movimentos próprios da classe trabalhadora, de seus sindicatos, de suas entidades representativas, de seus fóruns de debates. É comum hoje vermos muitos e muitos profissionais afirmando coisas do tipo: "não participo desse ou daquele movimento porque são movimentos políticos, e minha atuação é técnica e não política...". Tem-se até a impressão de que esses colegas se consideram como uma "elite" que não está sujeita aos mesmos constrangimentos societários que a classe trabalhadora em geral sofre. E presas fáceis dos processos de alienação, muitos assistentes sociais não conseguem dar o passo seguinte, ou até simultâneo, às suas intervenções profissionais, que é o passo da participação nos movimentos coletivos e organizados de sua classe. 
Para finalizar, é importante destacar que a atuação de um assistente social nessa área não pode estar a serviço da culpabilização, da vigilância dos comportamentos ou dos julgamentos morais. Tampouco pode servir ao engodo de grande parte das instituições jurídicas que, em virtude da precarização e do desmonte que em seu interior foi promovido, ficam apenas fazendo "os processos judiciais andarem" com atos meramente burocráticos e burocratizantes.

Nosso trabalho tem que ser no sentido da oposição a esse estado de coisas, na resistência às mais diferentes formas de alienação, questionando e adensando nossos estudos sociais com os dados da realidade; levando para o interior dos autos dos processos o direito que vem "da rua", "dizendo o direito da rua" e dos movimentos sociais que também exigem justiça.

Nosso papel não é o de "decidir", mas o de criar conhecimentos desalienantes a respeito da realidade sobre a qual vai se deliberar naquilo que se refere à vida de pessoas. E há importantes espaços para isso no interior desse universo, uma vez que até mesmo os juristas mais conservadores sabem que a situação de fato impera sobre qualquer direito.

Marx escreveu em algum lugar:

"Direito contra direito, vence a força..."

Ousamos parafrasear o mestre alemão:

Direito contra direito pode vencer a força dos que se juntam na busca da real democratização das relações sociais, para a ultrapassagem da ordem do capital.

Recebido em 3/6/2013 - Aprovado em 10/6/2013 


\section{Referências bibliográficas}

AASPTJSP; CRESS-SP(Orgs.). Violência sexual e escuta judicial de crianças e adolescentes: a proteção de direitos segundo especialistas. São Paulo: Associação dos Assistentes Sociais e Psicólogos do Tribunal de Justiça do Estado de São Paulo e Conselho Regional de Serviço Social do Estado de São Paulo, 2012.

AGUINSKY, Beatriz G.; HUFF DE ALENCASTRO, Ecleria. Judicialização da questão social: rebatimento no processo de trabalho dos assistentes sociais no Poder Judiciário. Katalysis, Florianópolis, jan./jun. 2006.

ALAPANIAN, Sílvia. Serviço Social e o Poder Judiciário: reflexões sobre o direito e o Poder Judiciário. São Paulo: Veras, 2008. v. 1.

AZAMBUJA, Maria Regina Fay de. Inquirição de criança vítima de violência sexual: proteção ou violação de direitos? Porto Alegre: Livraria do Advogado, 2011.

BORGIANNI, Elisabete. Para que a positividade capitalista não triunfe sobre a razão: estudo preliminar das contribuições de Georg Lukács. Dissertação (Mestrado) — Pontifícia Universidade Católica, São Paulo, 1997.

Risco-país e investment grade: contribuição do Serviço Social para sua desmistificação. Tese (Doutorado) — Pontifícia Universidade Católica, São Paulo, 2008.

Identidade e autonomia do trabalho do/a assistente social no campo sociojurídico. In: CONSELHO FEDERAL DE SERVIÇO SOCIAL. II Seminário Nacional: o Serviço Social no campo sociojurídico na perspectiva da concretização de direitos. Brasília: CFESS, 2012.

O Serviço Social no "campo sociojurídico": primeiras aproximações analíticas a partir de uma perspectiva crítico-ontológica. In: ; FUZIWARA, A. S.; ALBUQUERQUE, V. O. O Serviço Social na área sociojurídica: segundo relatório da assessoria técnica: mapeamento das atribuições na área sociojurídica. São Paulo: CFESS, 27 jan. 2013.

BOURDIEU, Pierre. A economia das trocas simbólicas. 5. ed. Tradução Sérgio Miceli. São Paulo: Perspectiva, 1999.

CARLI, Ranieri. Gyorgy Lukács e a especificidade da política: o lugar da práxis política em uma ontologia do ser social. Rio das Ostras, 2012. (Mimeo.)

COLMÁN, Silvia Alapanian. A formação do Serviço Social no Poder Judiciário: reflexões sobre o direito, o Poder Judiciário e a intervenção do Serviço Social no Tribunal de Justiça do Estado de São Paulo de 1948 a 1988. Tese (Doutorado) — Pontifícia Universidade Católica, São Paulo, 2004. 
CONANDA. Resolução n. 113. Dispõe sobre o Sistema de Garantia dos Direitos de Crianças e Adolescentes. Brasília: SEDH, Conselho Nacional dos Direitos da Criança e do Adolescente, 19 abr. 2006.

DAHMER, Tânia. Competências e atribuições profissionais na LEP. In: CONSELHO FEDERAL DE SERVIÇO SOCIAL. II Seminário Nacional: o Serviço Social no campo sociojurídico na perspectiva da concretização de direitos. Brasília: CFESS, 2012.

DELFINO, Lúcio. Insatisfações, lides, pretensões e resistências. Disponível em: $<$ http://www.mundojuridico.adv.br>. Acesso em: 22 abr. 2013.

FÁVERO, Eunice Terezinha. Serviço Social, práticas judiciárias, poder: implantação e implementação do serviço social no Juizado de menores de São Paulo. São Paulo: Veras, 1999.

O estudo social: fundamentos e particularidades de sua construção na área judiciária. In: CFESS (Org.). O estudo social em perícias, laudos e pareceres técnicos. São Paulo: Cortez/CFESS, 2003.

. Serviço Social no campo sociojurídico: possibilidades e desafios na consolidação do projeto ético-político. In: CONSELHO FEDERAL DE SERVIÇO SOCIAL. II Seminário Nacional: o Serviço Social no campo sociojurídico na perspectiva da concretização de direitos. Brasília: CFESS, 2012.

GAGLIETTI, Mauro. O discurso jurídico como articulador da "sociedade". Serviço Social \& Sociedade, São Paulo, Cortez, n. 60, p. 83-91, jul. 1999.

IAMAMOTO, M. V. Serviço Social em tempo de capital fetiche: capital financeiro, trabalho e questão social. São Paulo: Cortez, 2007.

Posfácio. Questão social, família e juventude: desafios do trabalho do assistente social na área sociojurídica. In: SALES, M. A.; CASTRO DE MATOS, M.; LEAL, M. C. (Orgs.). Politica social, família e juventude. São Paulo: Cortez, 2004, p. 261-314.

Prefácio. Projeto profissional e trabalho do Assistente Social: o Serviço Social no Tribunal de Justiça do Estado de São Paulo. In: FÁVERO, E. T.; MELÃO, M. J. R.; JORGE, M. R. T. O Serviço Social e a psicologia no Judiciário: construindo saberes, conquistando direitos. São Paulo: Cortez/AASPTJ-SP, 2005.

; CARVALHO, R. Relações sociais e Serviço Social no Brasil: esboço de uma interpretação histórico-metodológica. São Paulo: Cortez/Celats, 1982.

LEAL, M. C.; CASTRO DE MATOS, M.; SALES, M. A. Política social, família e juventude: uma questão de direitos. São Paulo: Cortez, 2004. 
NETTO, José Paulo. FHC e a política social: um desastre para as massas trabalhadoras. In: LESBAUPIN, I. (Org.). O desmonte da nação: balanço do governo FHC. Petrópolis: Vozes, 1999.

NOGUEIRA NETO, Wanderlino. A judicialização da questão social: desafios e tensões na garantia de direitos. In: CONSELHO FEDERAL DE SERVIÇO SOCIAL. II Seminário Nacional: o Serviço Social no campo sociojurídico na perspectiva da concretização de direitos. Brasília: CFESS, 2012.

PASUKANIS, Evgene. Teoria geral do direito e o marxismo. Coimbra: Centelha, 1977.

PEQUENO, Andreia Cristina Alves. Prefácio. In: CONSELHO REGIONAL DE SERVIÇO SOCIAL DO RIO DE JANEIRO (Cress/7 Região). O Serviço Social e o sistema sociojurídico. Em Foco, Rio de Janeiro, n. 2, p. 11-14, maio 2004.

PIOVESAN, Flávia; VIEIRA, Renato Staziola. Justiciabilidade dos direitos sociais e econômicos no Brasil: desafios e perspectivas. Araucaria, revista iberoamericana de filosofia, política e humanidades, ano $8, \mathrm{n} .15,1^{\circ}$ sem. 2006. Disponível em: <http://institucional. us.es/araucaria/nro15/nro15.htm>. Acesso em: 21 abr. 2013.

SARTORI, Vitor Bartoletti. Lukács e a crítica ontológica ao direito. São Paulo: Cortez, 2010.

SÊDA, Edson. A criança, a política e a justiça. Rio de Janeiro: Adês, 2007.

SHIRAISHI NETO, Joaquim. O campo jurídico em Pierre Bourdieu: a produção de uma verdade a partir da noção de propriedade privada nos manuais de direito. Sequência, Florianópolis, UFSC, v. 29, n. 56, p. 83-100, 2008.

TEJADAS, Sílvia da Silva. O direito humano à proteção social e sua exigibilidade: um estudo a partir do Ministério Público. Curitiba: Juruá, 2012.

TORRES, Andrea Almeida. Para além da prisão: experiência significativa do Serviço Social na Penitenciária Feminina da Capital (1978-1983). Tese (Doutorado) — Pontifícia Universidade Católica, São Paulo, 2005.

YAZBEK, M. C. O Serviço Social como especialização do trabalho coletivo. In: CFESS/ Abeps e CEAD/UnB (Orgs.). Crise contemporânea, questão social e Serviço Social: capacitação em Serviço Social e política social. Módulo 2. Brasília: Cead/UnB, 1999. 